\title{
Analysis of the Opportunities for Motor Development in Home Environments of Infants Served in an Early Stimulation Sector
}

\author{
Rosane Carneiro Pereira da Silva", \\ Milena Nunes Alves de Sousa ${ }^{2}$, Elicarlos Marques Nunes ${ }^{3}$, \\ Célio Diniz Machado Neto ${ }^{4}$, \\ Viviane Valéria de Caldas Guedes Garcia5, \\ Adriano Moura de Menezes Dantas ${ }^{6}$, Polianne Medeiros \\ Brito $^{5}$, Mayara Leal Almeida Costa7, \\ Nicoly Negreiros de Siqueira Mariano ${ }^{8}$, \\ Larissa de Araújo Batista Suarez ${ }^{9}$, \\ Paula Christianne Gomes Gouveia Souto Maia ${ }^{10}$, \\ Petrônio Souto Gouveia Filho'11, \\ Everson Vagner de Lucena Santos ${ }^{12}$, \\ Aucélia Cristina Soares de Belchior ${ }^{13}$, \\ Rosângela Maria Fernandes de Oliveira ${ }^{4}$, \\ Manuela Carla de Souza Lima Daltro ${ }^{14}$
}

\section{Abstract}

Introduction: The home environment has been appointed as the extrinsic factor that most influences child development.

Objective: The objective is analyzing the opportunities for motor development in homes of infants treated at an early stimulation sector in Paraiba.

Method: The study was conducted in an early stimulation sector of a Physiotherapy School Clinic of a Higher Education Institution in the state of Paraiba, Brazil, and consisted of 10 infants' parents attended. The instrument used was the questionnaire Affordances in the Home Environment for Motor Development (AHEMD) 18-42 months. After the questionnaire application, the data collected were introduced and classified with the help of a Microsoft Excel application (AHEMD Calculator VPbeta 1.5.xls).
1 Physiotherapist graduated from*

2 Nurse. Doctor in Health Promotion by Franca University. Teacher at Department of Medicine of*

3 Nurse. Master in Public Health. Teacher at Department of Nursing of*

4 Physiotherapist. Teacher at Department of Physical Therapy of*

5 Physiotherapist. Master in Public Health Teacher at Department of Physical Therapy of*

6 Doctor. Master in Public Health, Faculty of Medicine of ABC. Teacher at Department of Medicine of *

7 Physiotherapist. Master of Science in Education, Teacher at Department of Physical Therapy of*

8 Doctors. Teacher at Department of Medicine of*

9 Psychologist. Teacher at Departiment of Information Systems of*.

10 Doctor. Master in science and engineering of materials. Teacher at Departiment of Medicine of*

11 Nurse. Master in Coletive Health and Hospital Management. Teacher at Department of Medicine of*

12 Physiotherapist. Master in Coletive Health. Teacher at Department of Physical Therapy of*

13 Physiotherapist. Doctor. Teacher at Department of Physical Therapy of*

14 Physiotherapist. Master in Health Sciences, Teacher at Department of Physical Therapy of*

$$
\text { *: Patos Integrated College, Patos (PB), Brazil. }
$$

Contact information:

Elicarlos Marques Nunes.

Address: Bossuet Wanderley, 521 Apto. 101, Bairro: Centro. CEP: 58700-070, Patos (PB), Brasil.

” elicarlosnunes@yahoo.com.br 
Results: The results obtained are numbered 1 to 5 , where 1 is a very weak stimulation, 2 poor, 3 good, 4 very good and 5 excellent. It was used the SPSS statistical program for descriptive analysis of the frequency distribution of the subscales, gender and income. It was observed that although the sample investigated show a good level of domestic household stimulation, favoring, therefore, the motor development, is still very weak the existence of external home stimulation and materials that stimulate the fine and gross motor skills of children in developing.

Conclusions: So, it was found that, in general, the opportunities present in the home show as inefficient to promote motor development of children.

\section{Keywords}

Physiotherapy; Ambulatory Care; Early Intervention.

\section{Introduction}

Child development is a process that starts from intrauterine life involving various aspects, such as neurological maturation, physical growth and building of skills related to behavior and cognitive, emotional and social spheres of the child. The first years of human life are marked by motor physical, mental and social important formations, and the period in which the child has special sensitivity to environmental stimuli from which come to it through their senses [1].

Motor development occurs with great intensity in childhood, during which there is a wide plasticity of the central nervous system, allowing an increase in engine and integrated systems gains [2-4]. The first two years of life are critical for child development, occurring rapid brain growth and intense cognitive and sensorimotor advance, which can be influenced by a number of biological and environmental factors [5].

Child development is influenced not only by biological issues, but others such as prematurity, en- vironmental factors, parental education, family dynamics and socio-economic structure of the family [6]. Among them, the home environment has been appointed as the extrinsic factor that most influences child development [7].

The physical structure of the houses consisted of indoor and outdoor spaces is of great importance because it is the child's first media experience in their early years of life [8]. Also, furniture, toys, and care provided by caregivers, configure the opportunities in the home with possible repercussions on developing of children's motor skills [7], socioeconomic status may be a factor that intervenes or not [9-10].

The environment in which the child lives influences in their motor learning, and the house is the main agent of learning and development. Cultural practices, toys and games available to children, influence the development of their motor skills and, especially, in their parents' encouragement in this process. The mother or caregiver should observe her child, encourage him and arrange for him to be 
offered toys or equipment that can help you in his development and training [7, 11].

Therefore, this study aimed to analyze the opportunities for children's motor development in a domestic environment.

\section{Methods}

This was a field research, of applied nature, with a quantitative approach and exploratory objectives, which was held in a Clinical School of Physiotherapy of a Higher Education Institution (HEI), located in a city of high backlands of Paraiba. It had beginning with the application of research during the second half of 2014, after being approved by the Ethics Committee in Research under protocol number 31100914.4.0000.5181.

The population consisted of 20 parents of infants assisted in an early stimulation sector that are undergoing treatment in the chosen institution. And the study sample was made up of the parents of these children, chosen at random, adding to the total a sample of 10 parents. To be included in the survey, the parents must meet the following criteria: have a child in the early stimulation treatment sector of the institution; not to oppose to participate; not have done some research on the subject matter and sign the Free and Informed Consent Term. Exclusion criteria are parents who did not meet the above criteria.

The instrument used was the questionnaire Affordances in the Home Environment for Motor Development (AHEMD) 18-42 months. This is a questionnaire with the initial part intended to identify the characteristics of the child and family, and 67 questions related to family environment, divided into five subscales: outer space, inner space, variety of stimulation, fine motor materials and coarse motor equipment.

After the questionnaire, the data were introduced and classified with the help of a Microsoft Excel application (AHEMD Calculator VP beta 1.5.xls). The results are numbered 1 to 5 , where 1 corresponds to very weak stimulation, 2 weak, 3 good, 4 very good and 5 excellent. SPSS was used for descriptive analysis of the frequency distribution of the subscales, gender and income.

\section{Results}

It was analyzed 10 children, 08 male $(80.0 \%)$ and 02 females (20.0\%) aged between 18-42 months. It was also seen that 7 children (70.0\%) have a family income below 1000.00 and only 03 (30.0\%) above 1000.00.

There was a prevalence of male children. Different from what was shown in the study of Pilattiet al. [12], with more female children (57.1\%) than males (42.9\%). (Tables 1, 2, 3, 4 and 5)

Table 1. Standardized Value with respect to the external environment.

\begin{tabular}{|l|c|c|c|c|} 
& Frequency & Percentage & $\begin{array}{c}\text { Percentage } \\
\text { Valid }\end{array}$ & $\begin{array}{c}\text { Percentage } \\
\text { Cumulative }\end{array}$ \\
\hline Very weak & 7 & 70.0 & 70.0 & 70.0 \\
\hline Weak & 3 & 30.0 & 30.0 & 100.0 \\
\hline Total & 10 & 100.0 & 100.0 & \\
\hline
\end{tabular}

Source: data obtained on the period of October 2014.

Table 2. Standardized Value with respect to the internal environment.

\begin{tabular}{|l|c|c|c|c|} 
& Frequency & Percentage & $\begin{array}{c}\text { Valid } \\
\text { Percentage }\end{array}$ & $\begin{array}{c}\text { Cumulative } \\
\text { Percentage }\end{array}$ \\
\hline Weak & 2 & 20.0 & 20.0 & 20.0 \\
\hline Very good & 8 & 80.0 & 80.0 & 100.0 \\
\hline Total & 10 & 100.0 & 100.0 & \\
\hline
\end{tabular}

Source: data obtained on the period of October 2014.

Table 3. Standardized value with respect to the array of stimulation.

\begin{tabular}{|l|c|c|c|c|} 
& Frequency & Percentage & $\begin{array}{c}\text { Valid } \\
\text { Percentage }\end{array}$ & $\begin{array}{c}\text { Cumulative } \\
\text { Percentage }\end{array}$ \\
\hline Very weak & 5 & 50.0 & 50.0 & 50.0 \\
\hline Weak & 3 & 30.0 & 30.0 & 80.0 \\
\hline Good & 2 & 20.0 & 20.0 & 100.0 \\
\hline Total & 10 & 100.0 & 100.0 & \\
\hline
\end{tabular}

Source: data obtained on the period of October 2014. 
Table 4. Standardized Value with respect to the fine motor skills.

\begin{tabular}{l|c|c|c|c|} 
& Frequency & Percentage & $\begin{array}{c}\text { Valid } \\
\text { Percentage }\end{array}$ & $\begin{array}{c}\text { Cumulative } \\
\text { Percentage }\end{array}$ \\
\hline $\begin{array}{l}\text { Very weak } \\
\text { fraco }\end{array}$ & 9 & 90.0 & 90.0 & 90.0 \\
\hline Weak & 1 & 10.0 & 10.0 & 100.0 \\
\hline Total & 10 & 100.0 & 100.0 & \\
\hline & Source: data obtained on the period of October 2014. \\
\hline
\end{tabular}

Table 5. Standardized Value with respect to gross motor skills.

\begin{tabular}{|l|c|c|c|c|} 
& Frequency & Percentage & $\begin{array}{c}\text { Valid } \\
\text { Percentage }\end{array}$ & $\begin{array}{c}\text { Cumulative } \\
\text { Percentage }\end{array}$ \\
\hline Very weak & 9 & 90.0 & 90.0 & 90.0 \\
\hline Weak & 1 & 10.0 & 10.0 & 100.0 \\
\hline Total & 10 & 100.0 & 100.0 & \\
\hline
\end{tabular}

Source: data obtained on the period of October 2014.

\section{Discussion}

The parents' economic status appears to be related to greater access to information and, consequently, greater knowledge about the mechanisms that can generate more suitable motor development and stimulating environment for children. According to the literature, infants with better economic levels showed better opportunities for motor development [13].

When addressed about the external environment offered to children, it was observed that 7 children (70.0\%) have very weak environment and 3 (30.0\%) weak environment. (Table 1).

Regarding the internal environment offered to children, it was observed that 2 children (20.0\%) have weak environment and 8 children (80.0\%) very good atmosphere. (Table 2).

The findings highlighted in this study are in line with what was also observed in the study by Müller and Nobre et al. [10, 14], where it was found that the outer space of more than half of the analyzed households did not provide sufficient opportunities for motor development of children. These data indicate the need to promote an approach in the areas of civil engineering, architecture and physical education, specifically in engine development. May provide guidance for the development of architectural strategies that better structures the physical space of homes and public spaces. The same does not occur in interior space item, where most got very good rating, in both studies.

It was found that 5 children (50.0\%) presented a variety of very weak stimulation, $3(30.0 \%)$ week and 2 low (20, 0\%) solid. (Table 3).

Contrary to these results, in the study of Schobert [4]it was found that in $94.2 \%$ of the investigated homes, the array of stimulation was rated as very good. The same results were also found in Castro's study [15]. According to Stabelini Neto et al. [16], the stimulation is critical for child development, because it is from the motor operation that the child will develop the knowledge of itself and the external environment in which they live.

In the materials that stimulate fine motor and gross motor skills, 9 children $(90.0 \%)$ had a very low level (Table 4 and 5).

The results were worrying for fine motor skills, which according to Godtsfriedt [17-20], with regard to materials and toys, whose handling involves the coordination of small muscles and coordination between eyes and hands, as well as to the coarse motor skills, which, for Silva [18-20], is the global dynamic movements (running, jumping, walking, etc.), important in improving the body dynamic balance, sensations and perceptions.

\section{Conclusions}

According to the obtained data, it can be observed that, although the sample studied show a good level of internal home stimulation, favoring, therefore, themotor development, is still very weak the existence of external home stimulation and materials that encourage fine and gross motor skills of 
the developing child. Therefore, it was found that, in general, the opportunities present in the home show to be inefficient to promote motor development of children. It is necessary to emphasize the importance of knowledge that health professionals should have on environmental stimulation for child development. In order that, in the present study, we used a limited number of patients, it is suggested future work up using a larger sample, a fact which will enable, thus, higher reliability compared to the results.

\section{References}

1. Saccani R, Brizola E, Giordani AP, Bach S, Resende TL, Almeida CS. Assessment of neuropsychomotor development in children of a neighborhood on the outskirts of Porto Alegre. Scientia Medica. 2007; 17 (3): 130-7.

2. Almeida CSD. Motor intervention: effects on infant behavior in the third quarter of life in Porto Alegre daycare. 2004.

3. Rech DMR. Influences of a motor education program with three different interventional approaches in preterm infants motor performance. 2005.

4. Schobert L. Babies motor developing in nurseries: a look at different contexts. 2008.

5. Walker SP, Wachs TD, Gardner JM, Lozoff B, Wasserman GA, Pollitt E, Carter JA. Child development: risk factors for adverse outcomes in Developing Countries. The lancet. 2007; 369 (9556): 145-57.

6. Kolobe TH. Childrearing practices and developmental expectations for Mexican-American mothers and the developmental status of Their infants. Physical Therapy. 2004; 84 (5): 439-53.

7. Rodrigues L, Gabbard C. Evaluation of opportunities for motor stimulation present at the family home: projectoaffordances in the home environment for motor development. Motor development of children. Lisbon: FMH Editions. 2007: 51-60.

8. Haydari A, Askari P, Nezhad MZ. Relationship between affordances in the home environment and motor development in children age 1842 months. Journalof Social Sciences, 2009; n. 5 , v. 4, p. $319,328$.

9. Freitas TCB. Relationship between the opportunities for motor stimulation present in the home environment and socioeconomic status of the family [dissertation]. Piracicaba: Methodist University of Piracicaba. 2011.

10. Nobre FSS, Costa CLA, Oliveira DL, Cabral DA, Nobre CC, Caçola P. Analysis of the opportunities for motor development (affordances) in the home environment in Ceará, Brazil. Brazilian Journal of human growth and development. 2009; 19 (1): 9-18.
11. Rodrigues LP, Saraiva LC. Gabbard Development and construct validation of an inventory is assessing the home environment for motor development. Research quarterly for exercise and sport. 2005; 76 (2): 140-8.

12. Pilatti I, Haas T, Sachetti A, Fontana C, Oliveira SG, Schiavinato JCC. Opportunities for Child Motor Development in Home Environments. Rev. bras. ciênc. Health, 2011; v. 9, no. 27, p. 2227.

13. Leite ICG, Defilipo EC, Fronio JS, Teixeira MTB, Bastos RR, Vieira MT, Ribeiro LC. Opportunities of home environment for motor development. 2012

14. Müller $A B$. Effects of motor intervention in different contexts in the development of children with motor delay. 2008.

15. Castro MBd. The influence of context on the basic motor skills of preschool and school. 2008.

16. Neto Stabelini A, Mascarenhas LPG, Nunes GF, Lepre C, Campos W. Relationship between environmental factors and basic motor skills in children aged 6 and 7 years. Magazine Mackenzie physical education and sport. 2004; 3 (3).

17. Godtsfriedt J. Motor development: global and fine motor skills. Taken from: http: // www. efdeportes. com / efd143 / motorglobal-and-thin. .htm; 2010.

18. Eickmann, SH, EMOND AM, Lima M. Evaluation of child development: beyond the neuromotor aspect. J. Pediatr. (Rio J.) [online] vol.92, n.3, suppl.1, pp.71-83. 2016.

19. Silva E. Hydrotherapy in the Elderly: Playing to be serious [completion of course work]. Florianópolis: University of Santa Catarina State; 1999.

20. Oliveira ALS, et al. Visual-Motor Maturity and Executive Functions in Schoolchildren. Paideia (Ribeirão Preto) [online]. vol.26, n.64, pp.215-223, 2016.
Publish in International Archives of Medicine

International Archives of Medicine is an open access journal publishing articles encompassing all aspects of medical science and clinical practice. IAM is considered a megajournal with independent sections on all areas of medicine. IAM is a really international journal with authors and board members from all around the world. The journal is widely indexed and classified Q2 in category Medicine. 